\title{
RESEARCH PAPER \\ Nitrogen and potassium in production, nutrition and water use efficiency in wheat plants
}

\author{
Janaina M. G. Carvalho, Edna M. Bonfim-Silva, Tonny J. Araújo da Silva, \\ Helon H.F. Sousa, Salomão L. Guimarães, and Adriano B. Pacheco \\ Universidade Federal de Mato Grosso, Instituto de Ciências Agrárias e Tecnológicas. Rondonópolis, Mato \\ Grosso, 78735-901, Brazil.
}

\begin{abstract}
J. M. G. Carvalho, E.M. Bonfim-Silva, T.J.A. Silva, Helon H.F. Sousa, S.L. Guimarães, and A.B. Pacheco. 2016. Nitrogen and potassium in production, nutrition and water use efficiency in wheat plants. Cien. Inv. Agr. 43(3):442-451. Wheat (Triticum aestivum L.) is a cereal used in food and feed for its nutritional properties. For nitrogen and potassium management, efficient use of water is required for greater availability and transportation of these nutrients. The objective of this study was to evaluate the effect of combinations of nitrogen and potassium doses in production, nutrition and water use efficiency in wheat. The experiment was held in a greenhouse with $8-\mathrm{dm}^{3}$ pots using Oxisol collected at a depth of 0-0.2 $\mathrm{m}$ under Cerrado vegetation. Base saturation was raised to $60 \%$. The experimental design was a randomized block in a $5 \times 5$ factorial arrangement with five doses of nitrogen $(0,100,200$, 300 and $\left.400 \mathrm{mg} \mathrm{dm}^{-3}\right)$ and potassium $\left(0,90,180,270,360 \mathrm{mg} \mathrm{dm}^{-3}\right)$ with four replications. Soil moisture was maintained by an auto-irrigation system ( $3 \mathrm{kPa}$ pressure). The experiment was collected at 95 days after plant emergence. We evaluated the dry mass of ears, shoots and roots, the total dry matter, nitrogen and potassium in grains, and the consumption and efficiency in water use. An analysis of variance and regression test at 5\% probability was conducted using SAS statistical software (SAS Institute, Inc., Cary, North Carolina). The nitrogen and potassium alone increased the dry mass of ears by $31.47 \%$ and $20.91 \%$, respectively. There was an interaction of nutrients on the dry mass of the shoots and the total dry matter. Potassium increases the concentration of nitrogen. Nitrogen and potassium promote gains in production, nutrition and water use efficiency.
\end{abstract}

Key words: nitrogen potassium ratio, production characteristics, Triticum aestivum.

\section{Introduction}

Wheat is one of the most commonly used cereals in the world for both food and feed. Wheat has a diversity of genotypes that extends its adapta-

Received May 13, 2016. Accepted October 3, 2016. Corresponding author: embonfim@hotmail.com tion to different environmental conditions, and it can achieve high productivity in several regions (Pietro-Souza et al., 2013).

In the Cerrado soils of Central Brazil, highquality industrial wheat is produced that plays a major role in the market. According to Trindade et al. (2006), increased production of wheat in 
the Cerrado is due to the development of specific cultivars for this edaphoclimatic condition, as well as and also by other factors, such as proper soil management and the increased nutritional status of plants.

According to Espindula et al. (2010), grasses, such as wheat, do not benefit from biological nitrogen fixation with the same efficiency of legumes, so they must obtain nitrogen from the soil via fertilization.

Nitrogen is a macronutrient and is required in large quantities for the essential development and production of plants. Nitrogen is absorbed and exported to the grains in large quantities (Sousa and Lobato, 2004). Although high doses of nitrogen increase plant productivity through greater plant growth, this can also result in the lodging of some plants, such as wheat, rice, and other grasses, by negatively interfering with the yield and quality of grains (Buzetti et al., 2006). To reduce the risk of lodging in wheat cultures, it is important to use appropriate doses of nitrogen and manage fertilization with other nutrients, such as potassium.

Potassium is the second most absorbed element by plants. It is the most abundant cation in all cultures because it is present in the tissues, especially in water-soluble forms, and considered the most mobile nutrient in the soil-plant-atmosphere system, particularly for plants (Malavolta, 2005).

According to Zambolim and Ventura (2012), potassium operates in root growth and stimulates the uptake of water and nutrients. It reduces respiration, thus preventing energy loss by the plant, and aids in photosynthesis, sugar and starch translocation, starch enrichment in grain, increased protein content, and the prevention of disease.

Potassium facilitates the absorption and transport of nitrate to the shoot of the plant, which in turn increases the activities of nitrogen (Anjana et al.,
2009). The availability of nitrogen and potassium, and the proper ratio between them in the soil, are important factors in the growth and development of plants (Viana and Kiehl, 2010).

For more efficient absorption of these nutrients by the plants, a proper water content in the soil is necessary. Therefore, the study of water use efficiency is needed to ensure that plants have better production performance in low water availability, such as for conditions in the Brazilian Cerrado.

The continuous absorption of water is essential for plant growth and development, as most plants in tropical climates can lose more than their weight in water during the day under certain conditions (Pimentel, 2004).

In the present study, we aimed to evaluate the effect of combinations of nitrogen and potassium doses in the production, nutrition and water use efficiency in wheat plants.

\section{Materials and methods}

The experiment was carried out from June to October 2013 in a greenhouse at the geographical coordinates of $16^{\circ} 28^{\prime}$ latitude South and $50^{\circ} 34^{\prime}$ longitude West at an altitude of $284 \mathrm{~m}$. Inside the greenhouse, the average temperature and relative air humidity were $31^{\circ} \mathrm{C}$ and $73.8 \%$, respectively.

The soil used was classified as Oxisol and collected at a layer $0-0.20 \mathrm{~m}$ deep. The soil had the following chemical and physical characteristics: $\mathrm{pH}\left(\mathrm{CaCl}_{2}\right)$ : 4.1; P: $2.4 \mathrm{mg} \mathrm{dm}^{-3} ; \mathrm{K}: 28 \mathrm{mg} \mathrm{dm}^{-3}$; Ca: $0.3 \mathrm{cmol}_{\mathrm{c}} \mathrm{dm}^{-3} ; \mathrm{Mg}: 0.2 \mathrm{cmol}_{\mathrm{c}} \mathrm{dm}^{-3} ; \mathrm{Al}: 1.1$ $\mathrm{cmol}_{\mathrm{c}} \mathrm{dm}^{-3}$; H: $4.2 \mathrm{cmol}_{\mathrm{c}} \mathrm{dm}^{-3}$; V: 9.8\%; O.M: $24.8 \mathrm{~g} \mathrm{dm}^{-3}$; sand: $549 \mathrm{~g} \mathrm{~kg}^{-1}$; silt: $84 \mathrm{~g} \mathrm{~kg}^{-1}$; and clay: $367 \mathrm{~g} \mathrm{~kg}^{-1}$.

The soil was incubated with dolomitic lime for 30 days to raise the base saturation to $60 \%$ while maintaining the soil moisture at $60 \%$ of the maximum water holding capacity. 
An experimental randomized block design in a $5 \times 5$ factorial scheme was used with five doses of nitrogen $\left(0,100,200,300\right.$ and $\left.400 \mathrm{mg} \mathrm{dm}^{-3}\right)$ and potassium $\left(0,90,180,270,360 \mathrm{mg} \mathrm{dm}^{-3}\right)$ with four replications.

After liming, wheat sowing with the cultivar BRS 254 was conducted. Subsequently, the soil was fertilized with phosphate $\left(\mathrm{P}_{2} \mathrm{O}_{5}\right)$ at a dose of $300 \mathrm{mg} \mathrm{dm}^{-3}$ and micronutrients of boron, copper, and zinc at doses of $0.5 \mathrm{mg} \mathrm{dm}^{-3}, 0.8$ $\mathrm{mg} \mathrm{dm}^{-3}$ and $10.8 \mathrm{mg} \mathrm{dm}^{-3}$, respectively. Potassium chloride (PA) was used as the potassium fertilizer by plotting it twice. The first application was at planting. The other application was conducted with a nitrogen fertilizer when the plants reached approximately $15 \mathrm{~cm}$ in height. For nitrogen fertilization, urea (PA) was used as the source by plotting three times at an interval of one week for each application.

Vessels with a capacity for $8 \mathrm{dm}^{3}$ of soil were used in the experiment. The soil moisture control was conducted by using a subsurface auto-irrigation system, as described by Bonfim-Silva et al. (2007). This system is composed of a porous capsule (filter candle with a diameter of $5 \mathrm{~cm}$ and a height of 7 $\mathrm{cm})$ that is inserted into the vessel with the soil. The capsule is connected to a Mariotte bottle via a flexible microtube that is a PVC tube 100 $\mathrm{mm}$ in diameter and $30 \mathrm{~cm}$ long. This assembly allows for water replacement according to the needs of the plant. The water potential in the soil was established according to the height of the water column between the reservoir base and the middle of the capsule $(30 \mathrm{~cm})$, corresponding to a controlled tension on the surface of the 3-kPa capsule.

Daily readings of water consumption by wheat plants were conducted individually for each plot so that the total water consumption by plants in each treatment was obtained by the end of the crop cycle. The water use efficiency in wheat plants, depending on the nitrogen and potassium doses, was calculated by the ratio between production and total dry matter and water consumption in grams and liters, respectively.

At 95 days after sowing, the plants were cut off at ground level and packed in paper bags, identified and transferred to a forced-ventilation oven at $65^{\circ} \mathrm{C}$ until a constant mass was obtained. In this way, the dry mass of the shoots, which was composed of the dry mass of ears, leaves and stems, was obtained.

Next, the roots were washed, dried in the shade, and then packed in paper bags and transferred to a forced-ventilation oven at $65^{\circ} \mathrm{C}$ until a constant mass was reached. The dry mass of the roots, added to the dry mass of the shoots, resulted in the total dry matter.

The grains were separated from the ears, weighed with a semi-analytical scale and ground in a Wiley mill with 1-mm diameter sieves to determine the quantity of nitrogen and potassium.

The total nitrogen concentrations in the grains were measured with a micro-Kjeldahl methodology, as described by Malavolta et al. (1997), by using sulfuric acid digestion followed by distillation using the volumetric method.

Determination of the potassium concentration in the diagnostic leaves and grains was performed according to the methods proposed by Malavolta et al. (1997). The readings of the plant extract (with nitric-perchloric digestion) were obtained through atomic absorption spectrophotometry.

Data were statistically analyzed with "Statistical Analysis System" software (SAS Institute, 2002). Initially, the $\mathrm{F}$ test was conducted. For statistically significant cases $(\mathrm{P} \leq 0.05)$ of nitrogen and potassium interaction, a polynomial regression analysis (response surface) was conducted using the RSREG procedure. In the event of no statistical significance $(\mathrm{P}>0.05)$ from the RSREG procedure, the GLM procedure for regression studies was applied to the nutrient or nutrients that were found to be statistically significant in the $F$ test. 


\section{Results}

There was no statistically significant difference in the interaction between nitrogen and potassium doses to the dry mass of ears. However, there was a statistically significant effect for nitrogen and potassium alone, with an adjustment of results for the linear regression model.

Nitrogen fertilization increased the dry mass of ears by $31.47 \%$ when comparing the maximum nitrogen dose to the treatment with the absence of application of this nutrient (Figure 1A). The potassium rates affected the dry mass of ears, with an increase of $20.91 \%$ when comparing the higher dose $\left(360 \mathrm{mg} \mathrm{dm}^{-3}\right)$ with the treatment that did not receive potassium fertilizer (Figure 1B).

For the dry mass of wheat shoots, there was a statistically significant interaction between the nitrogen and potassium doses (Figure 1C). In the response surface study for the dry mass of shoots, there was linear behavior. The maximum dry matter production was not observed within the range of the adopted doses of nitrogen and potassium in this study.

There was no statistically significant difference in the interaction between nitrogen and potassium doses to the dry mass of wheat roots. However, there was a statistically significant effect for both nitrogen and potassium alone, with adjustments of the results to the linear regression model.

The dry mass of roots ranged from 3.85 to 6.22 $\mathrm{g} \mathrm{pot}^{-1}$, with an increase of $38 \%$ when comparing the higher rate in the experimental range with the treatment that did not receive an application of nitrogen (Figure 2A). The potassium rates influenced the dry mass of roots, with an increase of $19 \%$ compared to the treatment without this nutrient (Figure 2B).

There was a statistically significant interaction between the nitrogen and potassium doses to the total dry matter in the response surface study
(Figure 2C). The nitrogen and potassium doses, for maximum dry matter yield, were not observed during the present study period (Figure 2C). Within each nitrogen dose, the dry matter yield increases due to an increase in potassium doses, and the same occurs with potassium. Thus, it can be inferred that the potassium supply increases because of fertilizer, and this nutrient influences a more efficient use of nitrogen by plants, which is reflected in increased production.

For the variable dry mass of grains, there was no significant difference between the treatments applied, but on the other hand, there was a significant influence of these on the concentrations of nitrogen and potassium in wheat grains.

In the analysis of variance for nitrogen concentration in wheat grains, there was no significant interaction between the nitrogen and potassium doses (Figure 3). Nonetheless, there was a significant response to the nitrogen concentration in the grains as a function of nitrogen and potassium, alone, with adjustment to the quadratic and linear regression model, respectively.

The concentration of nitrogen ranged from 27.70 to $35.52 \mathrm{~g} \mathrm{~kg}^{-1}$, the maximum concentration of nitrogen in the grains being observed in the nitrogen dose equivalent to $286.35 \mathrm{mg} \mathrm{dm}^{-3}$, with an increment of $22.02 \%$ (Figure $3 \mathrm{~A}$ ). As for the isolated effect of potassium fertilizer on nitrogen concentration in wheat grains, there was an increase of $11.82 \%$, when compared the higher dose of the experimental range with the treatment without potassium fertilizer (Figure 3B). This increase is due to the increased absorption by plants, in virtue of the greater availability of this nutrient in the soil, favoring thus the translocation of nitrogen for the grains.

Nitrogen rates contributed to potassium concentrations in the grains, and the nitrogen dose for maximum concentration increased by $26.4 \%$, when compared to the treatment with no application of this nutrient (Figure 3C). 

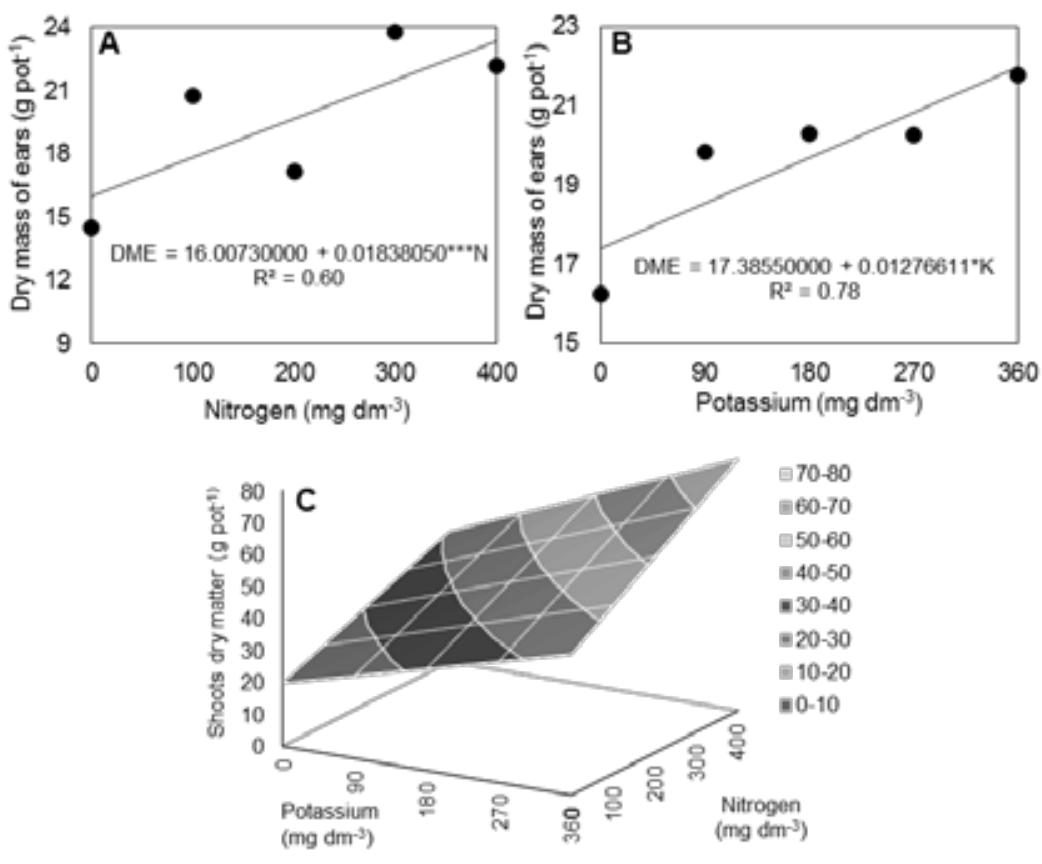

SDM $=19.763114+0.062675^{* *} \mathrm{~N}+0.067512^{* *} \mathrm{~K}+0.000094708^{* *} \mathrm{NK}$ $\mathrm{R}^{2}=0.60$

Figure 1. Dry mass of ears of wheat, depending on nitrogen (A) and potassium (B) rates, and dry matter yield of shoots $(C)$ of wheat, depending on fertilization with combinations of nitrogen and potassium rates, grown in Oxisol. The ***; ** and $*$ represent statistical significance at $0.1,1$ and $5 \%$, respectively.
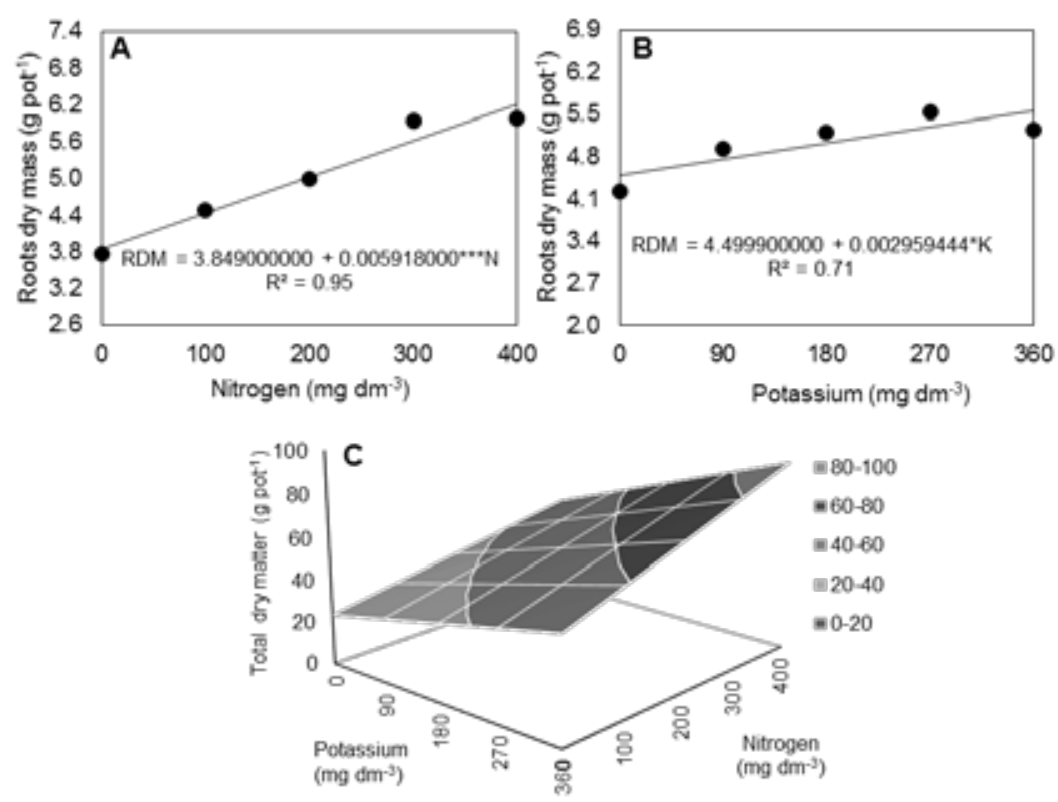

$\mathrm{TDM}=23636286+0.056425 * \cdots \mathrm{N}+0.071248 * \cdots \mathrm{K}+0.000122 * \cdots+\mathrm{NK}$ $R^{2}=0.63$

Figure 2. Dry mass of wheat roots that depend on nitrogen (A) and potassium (B) rates, and total dry matter yield (C) of wheat, depending on fertilization with combinations of nitrogen and potassium, grown in Oxisol. The $* * *, * *$ and $*$ represent statistical significance at $0.1,1$ and $5 \%$, respectively. 
For water consumption by wheat plants, there was no significant difference in the interaction of nitrogen and potassium combinations, as well as studying these nutrients alone. Hence, regardless of the influence of the doses of nitrogen and potassium on the productive development of wheat, water consumption was the same for all treatments.

For water use efficiency in wheat, it was found no significant interaction between nitrogen and potassium doses. Nonetheless, there were a significant effect of nitrogen (Figure 4A) and potassium (Figure 4B) levels alone, with adjustment of results to the linear regression model.

\section{Discussion}

The dry matter yield of ears is one of the shoot components that determine the production of wheat plants; some authors found the nitrogen contribution of yield components, as number of ears per square meter, number of grains per ear, thousand grain weight and other parameters (Valério et al., 2008).

According to Stefen et al. (2014), working with wheat $\mathrm{cv}$. Mirante submitted to the application of nitrogen in coverage and associated with the employment of growth retardants, the nitrogen, regardless of the growth retardants, significantly influenced the mass of grains per ear and thousand grain weight, and by studying the Spearman correlation carried out, they found positive correlation between mass of grains per ear and thousand grain weight $\left(\mathrm{R}=0.63^{* *}\right)$; and between thousand grain weight and grain yield $(\mathrm{R}=0.67 * *)$.

Trindade et al. (2006) evaluated the effects of nitrogen doses on the productivity of wheat in cultivars Embrapa 22 and Embrapa 42 under two irrigation managements in a no-till system. They found that nitrogen, regardless of the cultivar, increased the number of grains per $\mathrm{m}^{-2}$ and productivity with observed maximum values of nitrogen rates by
185.9 and $172.9 \mathrm{~kg} \mathrm{ha}^{-1}$, respectively. These authors also verified that productivity $\left(\mathrm{kg} \mathrm{ha}^{-1}\right)$ showed a statistically significant correlation $\left(\mathrm{R}=0.94^{* *}\right)$ with the number of grains per $\mathrm{m}^{-2}$.

Zagonel et al. (2002) worked with wheat cultivar OR-1 plant densities and nitrogen rates with and without a growth regulator (trinexapac-ethyl). In the presence of growth retardant, they observed that the highest number of ears per $\mathrm{m}^{-1}$ resulted from the highest nitrogen rate $\left(135 \mathrm{~kg} \mathrm{ha}^{-1}\right)$, which also improved grain productivity at the rate of $90 \mathrm{~kg} \mathrm{ha}^{-1}$.

The results of the present study agree with those found by Viana and Kiehl (2010), who evaluated the effects of combinations of nitrogen and potassium doses on the growth and assimilation of nitrogen by wheat plants They found a statistically significant interaction between the nutrients for dry matter production of shoots and verified that maximum production was obtained at nitrogen and potassium doses of $251 \mathrm{mg} \mathrm{dm}^{-3}$ and $200 \mathrm{mg}$ $\mathrm{dm}^{-3}$, respectively.

Good development of the root system is important for plant nutrition because it is the primary means of absorption for nitrogen and potassium assimilation. According to Bredemeier and Mundstock (2000), absorbed nitrogen can be assimilated in the root itself or be transported to the leaves for assimilation.

The results of this study differ from those found by Lavres Júnior and Monteiro (2002), who found a statistically significant interaction between nitrogen and potassium on the dry matter yield of Mombaça grass roots, where maximum production was observed in nitrogen and potassium levels of 467 and $396 \mathrm{mg} \mathrm{L}^{-1}$, respectively.

Batista and Monteiro (2006) assessed the root system of Marandu grass treated by nitrogen and sulfur in a nutrient solution. They found that the increase in dry mass of the roots was due to the nitrogen supply to the plants, with 

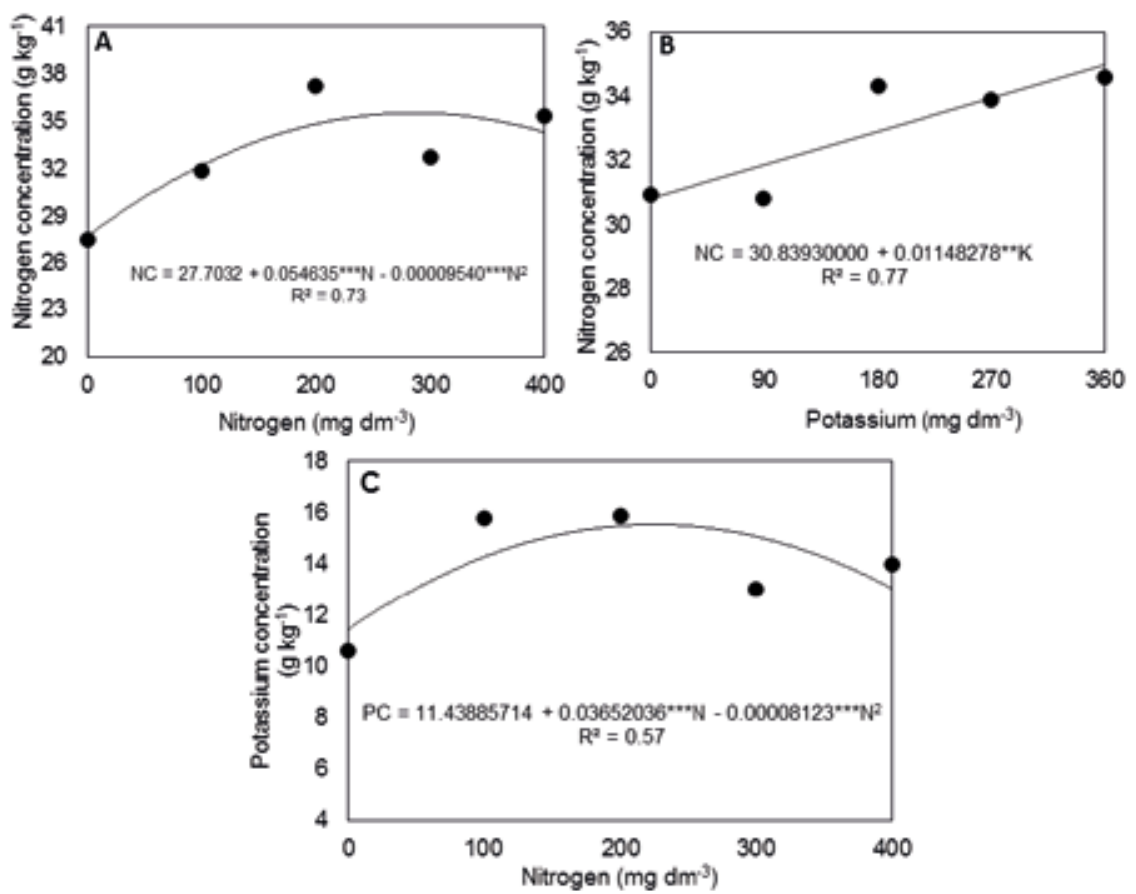

Figure 3. Nitrogen concentration in wheat grains, depending on nitrogen (A) and potassium (B) rates, and potassium concentration $(\mathrm{C})$ in wheat grains, depending on the levels of nitrogen, grown in Oxisol. The *** and $* *$ represent statistical significance at 0.1 and $1 \%$, respectively.
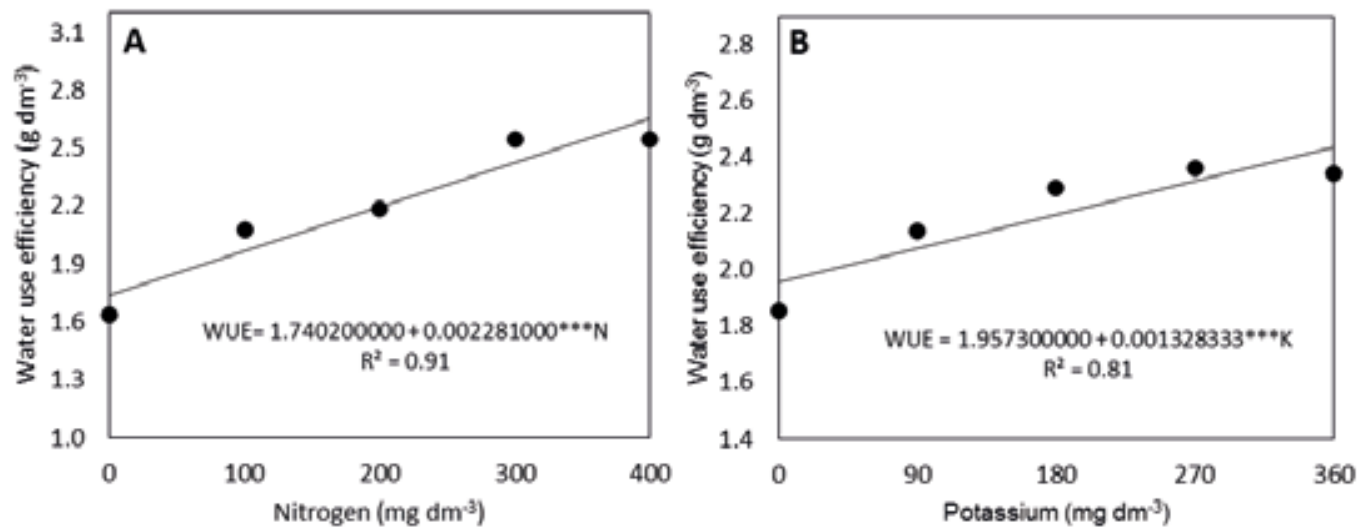

Figure 4. Water use efficiency (total dry matter/water consumption) in wheat, depending on nitrogen (A) and potassium (B) rates, grown in Oxisol. The *** represents statistical significance at $0.1 \%$ probability. 
adjustments to a square root model, where the maximum value of production exceeded the threshold used in the study, which was a nitrogen dose of $462 \mathrm{mg} \mathrm{L}^{-1}$.

Rosolem et al. (2012), when working with the addition of potassium in Oxisol, observed an increase in the dry mass of roots of Braquiaria $(B$. ruziziensis), with maximum production obtained in a potassium dose of $300 \mathrm{mg} \mathrm{dm}^{-3}$.

An increase in dry matter production, promoted by nitrogen fertilization, was also reported by Araújo et al. (2005), who evaluated the response of wheat (cv. IAC-24) to nitrogen via green manure and mineral fertilizer (urea). The authors highlighted that mineral fertilizer provides a rapid uptake of nitrogen by plants, generating a positive impact on dry matter production.

The results of the present study agree with those found by Trindade et al. (2006), when working with nitrogen application in coverage for two wheat cultivars (Embrapa 22 and Embrapa 42).

According to Malavolta et al. (1997), potassium is important in photosynthesis and in the formation and transport of carbohydrates and proteins in plants. Nitrogen assimilation is dependent on the photosynthetic activity of the plant. Therefore, it can be inferred that the nitrogen concentration in grains is linked to the nutritional status of potassium in the plant.

Niu et al. (2013) found a positive interaction between nitrogen and potassium, implying that potassium promotes absorption of nitrogen by plants.

In the present study, there was no statistically significant interaction between nitrogen and potassium doses for potassium concentration in wheat grains. However, we isolated the effect of applied nitrogen rates with adjustments to the quadratic regression model (Figure 3C).
These results contrast with those reported by Niu et al. (2013) who studied winter wheat and found that elevated potassium doses significantly increase the concentration of this nutrient in the grains.

In the present study, the nitrogen rates promoted an increase in the potassium concentration in wheat grains, which differed from the results found by Espindula et al. (2010). Through their work with wheat cv. Pioneiro that was grown in Ultisol, they observed that the potassium concentration in grains decreased with increasing nitrogen levels. They assigned this behavior to the dilution effect caused by the increase of drains (number of grains) provided by nitrogen.

An adequate supply of water is essential for wheat crops. Santos et al. (2012) studied the response of wheat genotypes subjected to water deficit and found that a water deficit adversely affects plant development by reducing biometric variables (height, leaf area, number of tillers) when compared with plants that were maintained with satisfactory moisture throughout the crop cycle.

Cossani et al. (2012) also observed that nitrogen tends to increase water use efficiency by $27 \%$, on average when working with barley and two species of wheat.

The influence of potassium on water use efficiency is explained by the fact that potassium is important for water maintenance in the plant by controlling the opening and closing of stomata when reducing transpiration (Ernani et al., 2007). In this way, one can explain the linear increase in water use efficiency for dry mass, which depends on the potassium levels in the fertilizer.

The supply of nitrogen and potassium in the soil promotes gains in the production and nutrition of wheat plants (cv BRS 254) grown in Oxisol. There is an interaction between nitrogen and potassium doses that results in increased dry mass of shoots and the total dry matter of wheat 
plants. Potassium promotes enhanced absorption and thereby increases use of nitrogen in the grains. Potassium concentrations in the grains are favored by nitrogen fertilization alone. The increase in production promoted by nutrients does not increase the consumption of water by wheat plants. Nitrogen and potassium increase water use efficiency in wheat plants.

\section{Acknowledgments}

The authors thank the Brazilian National Council for Scientific and Technological Development (CNPq) and Coordination for the Improvement of Higher Education Personnel (CAPES) for providing scholarships to the authors.

\section{Resumen}

J. M. G. Carvalho, E.M. Bonfim-Silva, T.J.A. Silva, H.H.F. Sousa, S.L. Guimarães y A.B. Pacheco. 2016. Nitrógeno y potasio en la producción, nutrición y eficiencia del uso de agua en plantas de trigo. Cien. Inv. Agr. 43(3):442-451. Trigo (Triticum aestivum L.) es un cereal utilizado en la alimentación humana y animal por sus propiedades nutritivas. En la gestión de nitrógeno y potasio, el uso eficiente del agua es necesaria para la mayor disponibilidad y el transporte de estos nutrientes. Este estudio tuvo como objetivo evaluar el efecto de las combinaciones de nitrógeno y potasio en la producción, la nutrición y la eficiencia en el uso del agua en trigo. El experimento se realizó en un invernadero con recipientes de $8 \mathrm{dm}^{3}$. Usando Oxisol, recogido a una profundidad de 0-0,2 $\mathrm{m}$ de área bajo la vegetación del Cerrado. La saturación de bases se aumentó a $60 \%$. El diseño experimental fue de bloques al azar en arreglo factorial $5 \times 5$ con cinco dosis de nitrógeno $\left(0,100,200,300 \mathrm{y} 400 \mathrm{mg} \mathrm{dm}^{-3}\right)$ y potasio $(0,90,180$, 270 y $\left.360 \mathrm{mg} \mathrm{dm}^{-3}\right)$ con cuatro repeticiones. La humedad del suelo se mantuvo con un sistema autoirrigante (mantenido en el potencial de $-3 \mathrm{kPa}$ ). El experimento foe cosechó después de 95 días de la emergencia. Se evaluaron la materia seca de las espigas, brotes, raíces, y materia seca vegetal total; nitrógeno y potasio en granos; el consumo y la eficiencia en el uso del agua. Las variables se sometieron a análisis de varianza y prueba de regresión al 5\% de probabilidad por el programa estadístico SAS. El nitrógeno y potasio, por separado, aumentaron el peso seco de las espigas, con incrementos de 31,47 y $20,91 \%$, respectivamente. Hubo interacción de nutrientes a la masa seca de la parte aérea y total. El potasio aumenta la concentración de nitrógeno. El nitrógeno y el potasio promueven ganancias en la producción, la nutrición y la eficiencia en el uso del agua.

Palabras clave: Características productivas, relación de nitrógeno:potasio, Triticum aestivum.

\section{References}

Anjana, S.U., and M. Iqbal. 2009. Effect of applied potassium in increasing the potential for $\mathrm{N}$ assimilation in spinach (Spinacea oleracea L.). Electronic International Fertilizer Correspondent 20: 8-10.

Araújo, A.S.F., G.M. Teixeira, A.X. Campos, F.C. Silva, E.J. Ambrosano, and P.C.O. Trivelin. 2005. Utilização de nitrogênio pelo trigo cultivado em solo fertilizado com adubo verde
(Crotalaria juncea) e/ou uréia. Ciência Rural 35: 284-289.

Batista, K., and F.A. Monteiro. 2006. Sistema radicular do Capim-Marandu, considerando as combinações de doses de nitrogênio e de enxofre. Revista Brasileira de Ciência do Solo 30: 821-828.

Bonfim-Silva, E.M., F.A. Monteiro, and T.J.A. Silva. 2007. Nitrogênio e enxofre na produção e no uso de água pelo capim-braquiária em degradação. Revista Brasileira de Ciência do Solo 31: 309317. 
Bredemeier, C., and C.M. Mundstock. 2000. Regulação da absorção e assimilação do nitrogênio nas plantas. Ciência Rural 30: 365-372.

Buzetti, S., G.C. Bazanini, J.G. Freitas, M. Andreotti, O. Arf, M.E. Sá, and F.A. Meira. 2006. Resposta de cultivares de arroz a doses de nitrogênio e do regulador de crescimento cloreto de clormequat. Pesquisa Agropecuária Brasileira 41: 1731-1737.

Cossani, C.M., G.A. Slafer, and R. Savin. 2012. Nitrogen and water use efficiencies of wheat and barley under a mediterranean environment in Catalonia. Field Crops Research 128: 109-118.

Embrapa. 2013. Sistema brasileiro de classificação de solos. 3 Ed. Rev. Ampl. Brasília. Embrapa: 353 pp.

Ernani, P.R., J.A. Almeida, and F.C. Santos. 2007. Potássio. In: Novais, R.F., V.V.H. Alvarez, N.F. Barros, R.L.F. Fontes, R.B. Cantarutti, and J.C.L. Neves Viçosa (eds.). Fertilidade do solo. Sociedade Brasileira de Ciência do Solo 375-470.

Espindula, M.C., M. Campanharo, V.S. Rocha, P.H. Monnerat, and L.F. Favarato. 2010. Composição mineral de grãos de trigo submetidos a doses de sulfato de amônio e trinexapac-etil. Pesquisa Agropecuária Tropical 40: 513-520.

Lavres Junior, J., and F.A. Monteiro. 2002. Combinações de doses de nitrogênio e potássio para a produção e nutrição do capim-mombaça. Boletim da Indústria Animal 59: 101-114.

Malavolta, E., G.C. Vitti, and S.A. Oliveira. 1997. Avaliação do estado nutricional das plantas: princípios e aplicações. 2 ed. Piracicaba. Potafos. 319 pp.

Malavolta, E. 2005. Potássio: absorção, transporte e redistribuição na planta. p. 179-230. In: Amada T., and Roberts T.L. Piracicaba (eds.). Potássio na agricultura brasileira. Instituto da Potassa e do Fosfato.

Niu, J., Z. Weifeng, S. Ru, X. Chen, K. Xiao, X. Zhang, M. Assaraf, P. Imas, H. Magen, and F. Zhang. 2013. Effects of potassium fertilization on winter wheat under different production practices in the north china plain. Field Crops Research 140: 69-76.

Pietro-Souza, W., E.M. Bonfim-Silva, A.F. Schlichting, and M.C. Silva. 2013. Desenvolvimento inicial de trigo sob doses de nitrogênio em Latossolo Vermelho de Cerrado. Revista Brasileira de Engenharia Agrícola Ambiental 17: 575-580.
Pimentel, C.A. 2004. Relação da planta com a água. Seropédica. EDUR. 191 pp.

Rosolem, C.A., J.P.T.M.M. Vicentini, and F. Steiner. 2012. Suprimento de potássio em função da adubação potássica residual em um Latossolo Vermelho do Cerrado. Revista Brasileira de Ciência do Solo 36: 1507-1515.

Santos, D., V.F. Guimarães, J. Klein, S.L. Fioreze, and E.K. Macedo Júnior. 2012. Cultivares de trigo submetidas a déficit hídrico no início do florescimento, em casa de vegetação. Revista Brasileira de Engenharia Agrícola Ambiental 16: 836-842.

SAS Institute. 2002, User's guide: statistics. $9^{\mathrm{TH}} \mathrm{Ed}$. CARY. 943 pp.

Sousa, D.M.G., and E. Lobato. 2004. Adubação com nitrogênio. In: Cerrado: correção do solo e adubação. Eds D.M.G. Sousa, E. Lobato. Planaltina. EMBRAPA Cerrados. p. 129-145.

Stefen, D.L.V., C.A. Souza, C.M.M. Coelho, M.E. Tormen, P.R. Zanesco, R.T. Casa, L. Sangoi, and F.R. Nunes. 2014. Adubação nitrogenada associada ao emprego de reguladores de crescimento em trigo cv. Mirante. Revista de Ciências Agroveterinárias 13: 30-39.

Trindade, M.G., L.F. Stone, A.B. Heinemann, A.D. Cánovas, and J.A.A Moreira. 2006. Nitrogênio e água como fatores de produtividade do trigo no Cerrado. Revista Brasileira de Engenharia Agrícola Ambiental 10: 24-29.

Valério, I.P., F.I.F. Carvalho, A.C. Oliveira, A.A. Machado, G. Benin, P.L. Scheeren, V.Q. Souza, and I. Hartwig. 2008. Desenvolvimento de afilhos e componentes do rendimento em genótipos de trigo sob diferentes densidades de semeadura. Pesquisa Agropecuária Brasileira 43: 319-326.

Viana, E.M., and J.C. Kiehl. 2010. Doses de nitrogênio e potássio no crescimento do trigo. Bragantia 69: 975-982.

Zagonel, J., W.S. Venâncio, R.P. Kunz, and H. Tanamati. 2002. Doses de nitrogênio e densidades de plantas com e sem regulador de crescimento afetando o trigo, cultivar OR-1. Ciência Rural 32: 25-29.

Zambolim, L., and J.A. Ventura. 2012. Mecanismos de ação do potássio na interação com doenças de plantas. p.105-134. In: L. Zambolim, J.A. Ventura, L.A. Zanão Júnior (eds.). Efeito da nutrição mineral no controle de doenças de plantas. Viçosa, Brazil. 